\title{
アトピー性度䖉炎に対する 低及応レベルレーザーの治療効果
} 森田秀樹、喜多野 征夫

兵庫医大皮筜科

Clinical Application of Low Reactive Level Laser Therapy

(LLLT) for Atopic Dermatitis

Hideki Morita and Yukio Kitano

Department of Dermatology, Hyogo College of Medicine, Hyogo

Abstract: Atopic dermatitis (AD) is one of the common chronic skin diseases in wi ich a variety of immunological disturbances have been described. Cyclosporin A, gamma interferon, and interleukin 2 were recently suggested for the management of the disease. They all act on some component of the immuological mechanism which provoke eczematous reactions. But because of side effects, we do not use these therapies as our first choice. Steroid ointment is still widely used for the treatment of AD. Steroid rosacea somtimes appears during the prolonged application of steroids. In the present study, we used a GaAlAs $830 \mathrm{~nm}$ diode laser for treatment of patients with atopic dermatitis. Immunohistological examination was also performed before and after LLLT. The following results were obtained. 1) l lchy sensation decreased in 79 of 112 cases (71\%) after this therapy. 2) Skin eruptions improved in 69 of 112 cases (62\%). 3) There were no side effects during and after LLLT. 4) Major histocompatibility complex (MHC) class ll antigen and intercellular adhesion molecule (ICAM)- l expression on epidermal cells decreased after the therapy. 5) The number of CDI positive epidermal dendritic cells did not significantly change before and after LLLT. Key words: GaAlAs diode laser therapy, atopic dermatitis

緒言

アトピー性皮膚炎(以下、AD) は診療面であり ふれた疾患であり、マスコミによる本疾患につ。 いての報道も多くなされ最近、社会的にも関心 の高まっている疾患である。ADは免疫学的に多 彩な興味深い所見が多く見出され、これらにつ
いての基礎的な研究報告が多くなされており、 我々も、ADにおける各種サイトカインや Eosinophil cationic protein(ECP)がADの病態

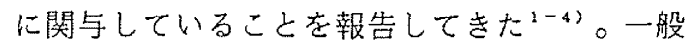
診療の場でADの治療に用いられているのは、免 疫学の進歩にもかかわらず以前より行われてい 
たステロイド外用療法に抗ヒスタミン剂や抗ア レルギー剤を加えた対症治療が主流である。こ れらの治療凨により多くのAD患者の皮疹峙軽快 するが、最近ではこれらの治療に抵抗性を示す $A D$ む增加しており、また、このような症例では ステロイドの長期外用による副作用む問題とな っている。実際、患者がステロイドの外用を拒 否したり、処方しても外用しない例が増えてい る。ステロイド離脱療法も試みられているが、 離脱によりステロイド皮痛症は改善するが、多 くの症例は抗原に暴露されると、皮疹は再燃す る。従ってADに対して有効加つ安全性の高い新 療法が望まれている。今回は最近我々が行って いる低反応レベルレーザー療法 (low reactive level laser therapy:LLLT)について紹介する.

目的

皮廉科領域におけるLLLTの臨床応用は、当初

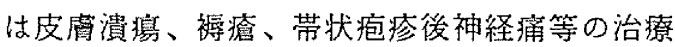
に用いられたが今回はADの治療に応用しその効 果について評価する。

\section{対象}

1991 年1 1 月から1993 年 4 月までの 間にLLLTで治療した112名（女性62名、男 性 50 名）のAD患者を対象とした。年路は 3 歳 から 45 歳で平均 18 藏であった。

\section{方法}

我々がADの治療に応用している機種は松下産 業機器製作の出力 $60 \mathrm{~mW}$, 波長 $830 \mathrm{~nm}$ のメデ1 レーザーソフトである。照射範囲および照射時 間は、100 $\mathrm{cm}^{2}$ の皮疹に対し 2 分間照射した。 治療前後の皮疹は我々のアレルギー外来で用い ている評洒法により評価しだ。膺痒感に関し ては患者に1０段階で答えさせ評価した。 5 名
の患者については同意を得て、治療前後に皮居 生検を施行。抗MHC Class II, ICAM-1，CD1の各 モノクローナル抗体をもちいた酵素抗体法によ る検索を併せて施行した。

結果

その結果治療を行った112例中79例、71\%に蛮 痒感が 10 段階評価法で 3 ポイント以上の軽減 が認められた。皮疹の改善は瘦痒感が軽減した 79例中69例に認められた。痋痒感が軽減するま でに要する時間は、1 時間以内 $8 \% 、 6$ 時間以 内 $28 \% 、 24$ 時間以内 $41 \% 、 24$ 時間以上 $23 \%$ あった。止痒効果の持続は 1 日以内 1 $3 \% 、 2-3$ 日 $42 \% 、 4-6$ 日 $21 \% 、 7$ 日 以上 $24 \%$ であったもノクロナール抗体を用 いて酵素抗体法により㭘討した結果、治療前で は表皮内にランゲルハンス細胞 (LC) と考えられ るMHC class 11抗原陽性樹枝状細胞が認められ た。これらの細胞は治療後において減数してい た。ICAM-1の発現は治療前では表皮基底膜周辺 の表皮細胞、及び、真皮血管内皮細胞に認めら れた。治療後では表皮細胞のICAM-1の発現はほ ぼ消失していた。しかし、血管内皮細胞のICAM -19発現は真皮上層部では消失していたが、中 層部以下では保持されていた。表皮内CD1陽性細 胞数は治療前後において差を認めなかった。

\section{考察}

LLLTは、数mWないし数十䀦のレーザー光を利 用するすので、ソフトレーザーとも㭔ばれてい る。レーザーの生体への作用は、高出カレーザ 一では、組織の切開、凝固など熱効果が主体で あるが、LLLTでは照射された組織は障害されず 消炎、鎮痛効果があることが知られている。レ ーザー光は単一波長の光であり、その生体反応 
を決定する因子は光作用に対する生体組織の光 学的特性によると考えられる。鎮痛効果を利用 した痛みに対する治療は既に整形外科、麻酔科 領域で臨床沈用がなされている ${ }^{5-も) 。 レ ー サ ゙ ー ~}$ 照射がADになぜ有効かを知る目的でレーザー照 射による治療前後の皮疹部を生検しモノクロ一 ナル抗体を用いた酵菜抗体法により検討したと ころ治療前に比し治療後では表皮内LCと考えら れるMHC class II 抗原陽性樹枝状細胞は減数し ていた。この所見の解䐆としては表皮内からLC が減数しているか、しCは残存しているがclass 11抗原の発現が減弱している可能性が考えられ る。LCのマーカーである表皮内CD1陽性細胞仙治 療前後において差を認めなかったため、LLLTに より表皮内抗原提示細胞は消失せず機能が低下 すると考元られる7”。表皮内I CAM-1晹性細胞す 治療後では減少していることを見いだした。血 管内皮細胞のICAM-1の発現は真皮上層部では隇 弱化しているが中層以下では保持されていた。 即ち、LLLTのICAM-1発現を指標とした深達度は 真皮上層部までと考えられた。接着因子の発現 を減弱させることによりリンパ球の皮简への浸 潤を抑制する作用が考えられる。臨床的には瘙 㾕感の軽減が認められるためレーザー照射は肥 満細胞の脱顆粒抑制作用も有しているか、棒み の神経伝達を抑制している可能性が想定される。

\section{結論}

$\mathrm{AD}$ は皮層科領域で現在最も注目されている族 患の一つである。今、時代のニードはステロイ ドの外用を如何に最小限にとどめるか、ステロ イド外用に变わる、或いは、減量でき、かっ、 安全性の高い治療法の開発である。現在、我々 が行っている、LLLTは時代の流れに沿った治療
法であると考えている。

文献

1) Morita H, Kihara T, Miyamoto M, Yamagata M. Sagami S: Interleukin-2 production of $T$ cells in atopic dermatitis, J Dermatol, 17:375-379, 1990.

2）菻田秀樹、木原貴子、池垣なつ、宮本美智 子、夏秋 儤、喜多野征夫、相模成一郎: アトピー性皮䖉炎にお打るインターロイキ ン6の臨床的意義、兵庫目医昞会雑誌、34 : $51-54,1991$.

3) Morita H, Kihara T, Tasumi Y, Kitano Y, Sagami S:Allergic granulomatosis and angiitis of Churg-Strauss -A case of high serum level of eosinophil cationic protein, Acta Derm Venereol(Stockh), 72 :201-202, 1992.

4）森田秀樹、堀美佳、木原貴子、山下紀子、 夏秋 僈、喜多野征夫、相模成一郎：アト ピー性皮成炎における血清ECPの検討、皮 虞科紀要、86:149-151，1991.

5）井上康二、西岡淳一、福田真輔：低出力 レーザー照射が慢性炎症におよぼす影響、 日本レーザー医学会誌、9:69-71，1988.

6) Asada K, Yutani Y, Sakawa A, Shimazu A: Clinical application of GaAlAs $830 \mathrm{~nm}$ diode laser in treatment of rheumatoid arthritis, Laser Ther, 3: 77-82, 1991.

7) Morita H, Kohno J, Hori M, Kitano Y: Clinical application of low reactive laser therapy for atopic dermatitis, Keio $\mathrm{J}$ Med, in press. 